.

\title{
Revision of the Conodont Mockina slovakensis and Its Paleogeographic Implications for the Upper Triassic Intraplatform Basins of the Alps
}

\author{
Yixing Du ${ }^{*}{ }^{1}$, Viktor Karádi ${ }^{2}$, Guido Roghi ${ }^{3}$, Maurizio Ponton ${ }^{4}$, Andrea Cozzi $^{5}$, Manuel Rigo ${ }^{1,3}$ \\ 1. Department of Geosciences, University of Padova, 35131 Padova, Italy \\ 2. Department of Palaeontology, Eötvös Loránd University, Budapest 1117, Hungary \\ 3. Institute of Geosciences and Earth Resources, National Research Council of Italy, 35131 Padova, Italy \\ 4. Department of Mathematics and Geosciences, University of Trieste, 34128 Trieste, Italy \\ 5. Eni Sharjah B.V., 73500 Sharjah, United Arab Emirates \\ (iD) Yixing Du: https://orcid.org/0000-0001-6397-1494
}

\begin{abstract}
Mockina slovakensis, thought to have evolved from Epigondolella praeslovakensis, is an important species of the Norian (Upper Triassic), generally considered as the representative of the uppermost Alaunian to upper Sevatian in the Tethys. The previous description of $M$. slovakensis was incomplete, thus has led to some misidentifications. We thus update the description of $M$. slovakensis and discuss its comparisons and occurrence based on the new conodont investigations in Dolomia di Forni and the data from previous literatures. The conodont assemblage in the succession of Dolomia di Forni is dominated by M. slovakensis, along with rare M. postera and E. praeslovakensis. We described two morphotypes of $M$. slovakensis (morphotypes $A$ and B), on the basis of shape of the lateral profile. These two morphotypes can also be observed in the $E$. praeslovakensis. Moreover, M. slovakensis is usually documented as almost monospecific conodont association in intraplatform basins, thus its paleogeographic implications are also discussed.
\end{abstract}

KEY WORDS: Mockina, conodont, morphotype, intraplatform basin.

\section{INTRODUCTION}

Mockina slovakensis is a kind of small pectiniform conodont element with distinctive characteristics occurring in the Upper Triassic. Its evolution from Epigondolella praeslovakensis was suggested by Moix et al. (2007), based on materials from Turkey. It has been chosen for the index species of the $M$. slovakensis Zone (uppermost Alaunian) due to its easy identification and widespread distribution in all marine environments (Rigo et al., 2018). Nevertheless, M. slovakensis caused some contentions since it was established by Kozur in 1972. The arguments mainly focused on the diagnosis and its stratigraphic range (Moix et al., 2007; Budai and Kovács, 1986). The integration of data from the new studies on the Dolomia di Forni Formation and available literature (Mazza et al., 2012; Balini et al., 2010; Belvedere et al., 2008; Moix et al., 2007; Bazzucchi et al., 2005; Channell et al., 2003; Donofrio et al., 2003; Kaya et al., 2001; Martini et al., 2000; Mastandrea et al., 1997; Gullo, 1996; Roghi et al., 1995; Budurov and Sudar, 1990; Kovács and Nagy, 1989; Budai and Kovács, 1986; Kozur, 1972) points

*Corresponding author: yixing.du@outlook.com

(C) The Authors 2021. This article is published with open access at Springerlink.com, corrected publication in 2021

Manuscript received September 26, 2020.

Manuscript accepted January 7, 2021. to the fact that $M$. slovakensis shows various morphological characteristics. These diversiform characteristics make the classification of $M$. slovakensis more confusing, however, it also provides traces of the evolutionary process.

Mockina slovakensis is also a typical, almost monospecific, conodont element usually collected from intraplatforms basins, and it has been used to understand the geodynamic evolution of the Late Triassic sector of the western Tethys.

Roghi et al. (1995) reported "Epigondolella" slovakensis and its clusters in Dolomia di Forni Formation, northeastern Italy. Based on new data from several sections in Forni area and the data from the previous studies, this study aims to discuss the morphological variety of $M$. slovakensis, the distribution of this species and the evolutionary process from E. praeslovakensis to M. slovakensis. The authors try to make a more complete understanding of this simple but also intricate Upper Triassic pectiniform conodont.

\section{GEOLOGICAL SETTING}

The Carnian Prealps (CP) belongs to the Eastern Alps and Southern Alps structural units. During Late Triassic the CP were a part of the Friuli-Dinaric Platform bordered to the north and east by the Carnian-Slovenian Basin (Fig. 1), the former links to the passive margin of the western Tethys (Schmid et al., 2004; Haas et al., 1995).

The Carnian Prealps is characterized by the presence of

Du, Y. X., Karádi, V., Roghi, G., et al., 2021. Revision of the Conodont Mockina slovakensis and Its Paleogeographic Implications for the Upper Triassic Intraplatform Basins of the Alps. Journal of Earth Science, 32(3): 657-666. https://doi.org/10.1007/s12583-021-1411-5. http://en.earth-science.net 
mainly shallow-water carbonate platform facies flanked by basinal ones, Upper Triassic-Lower Jurassic in age (Carulli et al., 2000). The Norian sedimentary succession started with the deposition of the peritidal deposits of the shallow-water carbonate platform represented by the Dolomia Principale Formation, followed by the Dachstein Limestone Formation, above a flat paleotopography originated by the partial filling of the pre-existing Carnian basins due to the increased terrigenous input during the Carnian Pluvial Event (e.g., Dal Corso et al., 2019; Rigo at al., 2007; Simms and Ruffell, 1989). During the Norian a series of NNE-SSW fault-bounded intraplatform basins were formed by an extensional tectonic phase. These intraplatform basins were characterized by limited vertical circulation and developed dysoxic to anoxic conditions. They are present in many sectors of the peritidal Dolomia Principale carbonate platform such as in Lombardy, Austria, Dolomites and NE Italy (Friuli-Venezia Giulia region) (Berra et al., 2007). In Lombardy, these intraplatform basins are represented by the Dolomie Zonate and Zorzino Limestone formations (Aralalta Group) (Berra et al., 2010; Jadoul, 1985); in the central Austroalpine by Ortles and Quattervals nappes (Berra and Jadoul, 1999; Berra, 1995); in the Northern Calcareous Alps (South Austria) by the Seefeld Schichten (Donofrio et al., 2003; Brandner and Poleschinski, 1986; Fruth and Scherreiks, 1984). In the eastern sector of the Southern Alps where the Carnian Prealps are located (Friuli-Venezia Giulia region), these intraplatform basins are represented by the Forni Dolomite Formation (Carulli et al., 1997; Mattavelli and Rizzini, 1974). The Forni Dolomite Formation is characterized by several hundred meters of laminated foetid dark limestones, dolostones and shales deposited mostly as calciturbidites and showing frequent graded and laminated bedding. In particular, the northern Mt. Verzegnis area has been interpreted as the depocenter area of Forni Dolomite intraplatform basin. In fact, the two Seazza and Forchiar sections consist of dark-gray to black or brown bituminous dolostone, sometimes in laminated thin layers, with chert nodules and lenses, but without (or rare) resedimented materials (Dalla Vecchia and Muscio, 1991).

In the westernmost part of the Carnian Prealps (Mt. Pramaggiore area), the Rovadia and Poschiedea sections are instead composed by laminated dolostones with resedimented breccias and calcarenites, while the Valmenone Section (Fig. 2) consists of thin intercalations of dark dolostones within the upper part of the Dolomia Principale Formation (Cozzi and Hardie, 2003; Cozzi, 2002; Cozzi and Jäger, 2000). Similar outcrops are found in the southernmost part of Carnian Prealps, where dark and laminated dolostones and organic-rich laminated marls are intercalated within the Dolomia Principale Formation. Also, in the eastern Julian Prealps (Fig. 2), the same lithofacies are always intercalated within the Dolomia Principale Formation and they have been named Dolomia del Resartico Member (previously named "Rio Resartico organic laminated unit") with a thickness of tens of meters (Ponton, 2017; Fantoni et al., 1998).

To the east of the Dolomia Principale carbonate platform, the pelagic Slovenian Basin is characterized by the NorianRhaetian Bača and Slatnik formations (Rožič et al., 2009; Buser, 1996, 1989; Cousin, 1981, 1973). The connection between the southern Alps and the northern Calcareous Alps is instead represented by the basinal successions of the Transdanubian Central Range (Hungary), i.e., the Rezi Dolomite Formation in the southwestern Balaton Highland and the Feketehegy Formation in the Pilis Hills, characterized by restricted and suboxic

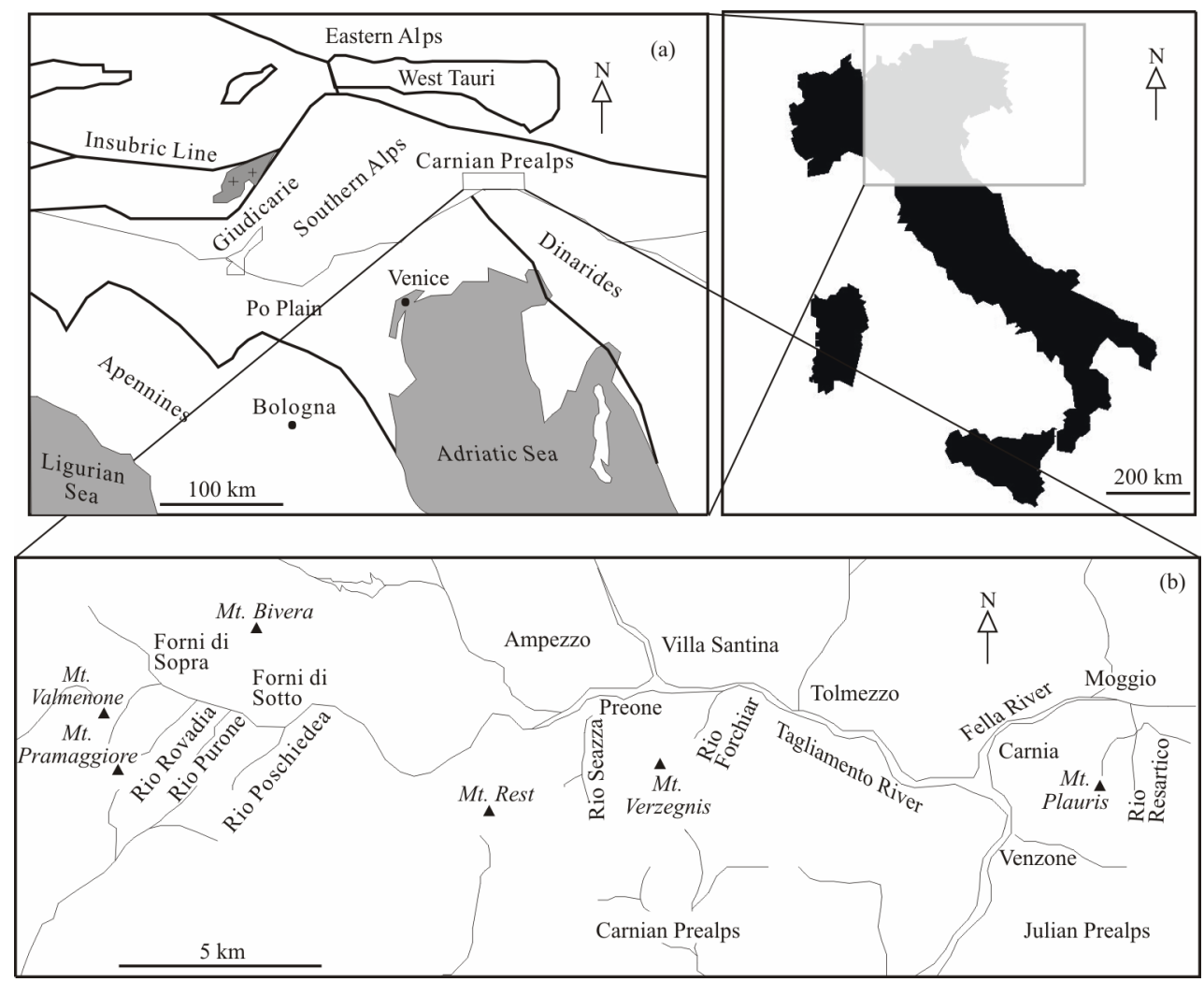

Figure 1. Structural map of NE Italy with the position of the Carnian Prealps (a) and the main localities of the studied sections (b). 


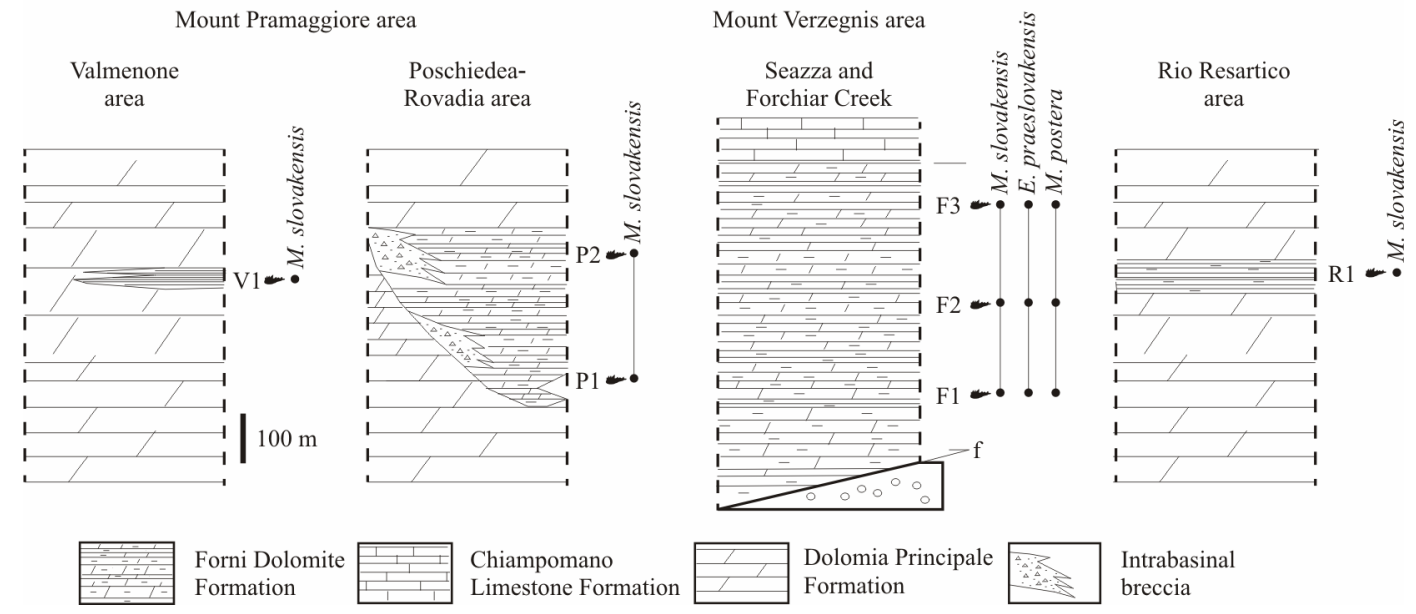

Figure 2. Schematic studied sections with the distribution of conodonts. See Fig. 1b for the geographic locations of the sections.

basins during the Norian (Haas, 2002; Csillag et al., 1995; Kovács and Nagy, 1989; Budai and Kovács, 1986).

\section{CONODONT BIOSTRATIGRAPHY}

The samples collected in the fossiliferous sections, that are the Valmenone, Poschiedea-Rovadia, Seazza and Forchiar Creek, and Rio Resartico, of the Dolomia di Forni area (Fig. 2), yielded large quantities of conodonts, including pectiniform elements, ramiform elements and clusters (Roghi et al., 1995). The reviewed conodont assemblage in this succession is dominated by Mockina slovakensis (Fig. 3), and there are also small numbers of concomitant $M$. postera and Epigondolella praeslovakensis. A previous study (Roghi et al., 1995) on conodonts in this area reported "Epigondolella" slovakensis, but some of the specimens, which own a bifurcated keel end are, instead, E. praeslovakensis. The conodont assemblage belongs to M. slovakensis Zone according to the Upper Triassic conodont biozonation of the Tethys by Rigo et al. (2018).

Mockina slovakensis is an important species of the Norian, generally considered as the representative of the uppermost Alaunian to upper Sevatian in the Tethys (Rigo et al., 2018).

\section{DISCUSSION}

\subsection{Previous Description of Mockina slovakensis}

In the original description of Mockina slovakensis (Kozur, 1972), the platform is about $2 / 3$ as long as the entire conodont element, being almost the same width everywhere. The anterior platform margins have three to five long denticles, but the posterior part of the platform is smooth with a rounded end. Some denticles can be accompanied by an accessory denticle. The blade is very high in the front and the denticles are strongly fused. Approximately in the middle, the blade breaks off like a cliff and three to four small and widely separated nodes follow to the rear but within the platform. The basal pit is shifted far forward and is approximately centrally located. However, Budai and Kovács (1986) emended the original description, since they thought the original description of $M$. slovakensis was based on a single and pathologic form. In their new description, the carina is the highest in the middle, then gradually decreases in height in phylogenetically earlier forms, but sharply drops down without transition in advanced elements.
The free blade is slightly inward bent and it comprises four to five completely fused denticles in adult. The wide keel extends along the whole length of the basal edge. The narrow, inverted pit is located near to center. Although they proposed some new diagnostic features, the abrupt decline of the blade and the strongly fused blade denticles were still the most distinctive characteristics of $M$. slovakensis. The new revision in Budai and Kovács (1986) optimized the description of M. slovakensis.

Furthermore, as more and more reports of M. slovakensis came out (e.g., Mazza et al., 2012; Rigo et al., 2012; Belvedere et al., 2008; Moix et al., 2007; Donofrio et al., 2003), we have found that there are large differences between certain individuals. We propose an improved description of the M. slovakensis population which is based on the integration data of the new investigation and the previous literature.

\subsection{Emended Description of Mockina slovakensis}

The platform of $M$. slovakensis is usually short. The shapes of the platform terminal are various and it could be pointed, rounded or blunt; the rounded and blunt platform terminal are likely to occur in the transitional forms; the pointed platform end almost only occurs in advanced form. The platform has 3-11 denticles (nodes) on the margins, generally with two high and sharp denticles on the external anterior margin and one on the internal anterior margin. The advanced form of $M$. slovakensis usually has 3-5 denticles on the anterior platform margins, and the posterior platform margins are nearly unornamented. In contrast, the posterior platform margins of the primitive forms or transitional forms between $M$. slovakensis and $E$. praeslovakensis are usually ornamented by small denticles or nodes. The pit is forward shifted and located in front of the middle of the platform, but it could backwardly lie in the central platform in the primitive forms. The keel end could be rounded or pointed but never bifurcated. The carina is composed of 2-6 denticles (nodes); generally, the carina of the advanced forms is shorter than those of the primitive and transitional forms. The posterior carina of the most M. slovakensis does not reach the end of the platform, but it could extend to the termination in some primitive and transitional forms, just like the E. praeslovakensis. The free blade usually consists of 2-6 strongly fused denticles and it has a wall-like termination where it descends abruptly to 


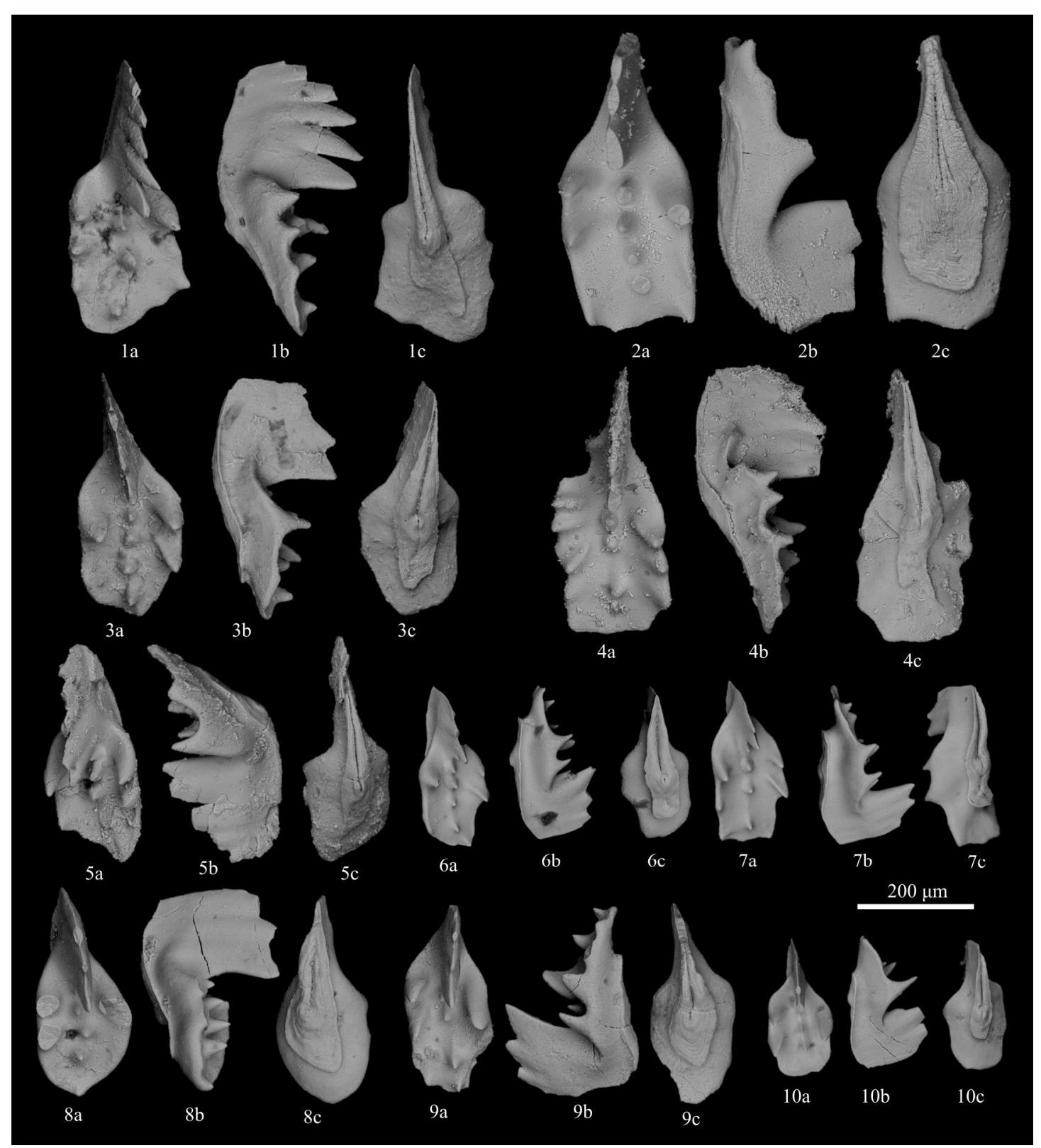

Figure 3. SEM photographs of conodonts from Dolomia di Forni. 1. Mockina slovakensis, P2, Poschiedea-Rovadia; 2. M. slovakensis, R1, Rio Resartico; 3. M. slovakensis, F1, Seazza and Forchiar Creek; 4. Epigondolella praeslovakensis, P1, Poschiedea-Rovadia; 5. M. slovakensis, P2, Poschiedea-Rovadia; 6. M. slovakensis, V1, Valmenone; 7. M. slovakensis, V1, Valmenone; 8. M. slovakensis, F1, Seazza and Forchiar Creek; 9. M. slovakensis, F2, Seazza and Forchiar Creek; 10. M. slovakensis, V1, Valmenone; a. upper view; b. lateral view; c. lower view.

the carina. The last denticle of the blade is usually huge and projected backwards. In lateral view, the morphotype A of the $M$. slovakensis population has an obviously elevated platform, making the profile of the element stepped; the lateral profile of morphotype B is slightly elevated or nearly straight.

\subsection{Morphotypes}

As more and more forms of the M. slovakensis population have been identified, Kovács and Nagy (1989) firstly divided the M. slovakensis into five morphotypes according to the shapes of platform and the distribution of ornamentation. But, in fact, the variation of the platform is diverse and it is not only five types.

During the investigation, we find that the shape of lateral profile shows two different forms in M. slovakensis population
(Fig. 4). The profile of the majority is stepped because of the elevated platform, but there is a small number of M. slovakensis shows a nearly straight profile. Thus, we classify the M. slovakensis into two morphotypes, $\mathrm{A}$ and $\mathrm{B}$, on the basis of shape of the lateral profile. Mockina slovakensis Morphotype A owns a stepped profile. In contrast, the lateral profile of M. slovakensis Morphotype B is nearly straight. These two morphotypes can also be found in the E. praeslovakensis.

In our study area, the two morphotypes are found together, but the occurrence of each morphotype is unclear in the other places. There are usually fewer figured specimens found in most previous literatures. In other literatures, M. slovakensis composes a monospecific fauna without any other age diagnostic fossils. Thus, the exact range of the two morphotypes is still unknown at present. 


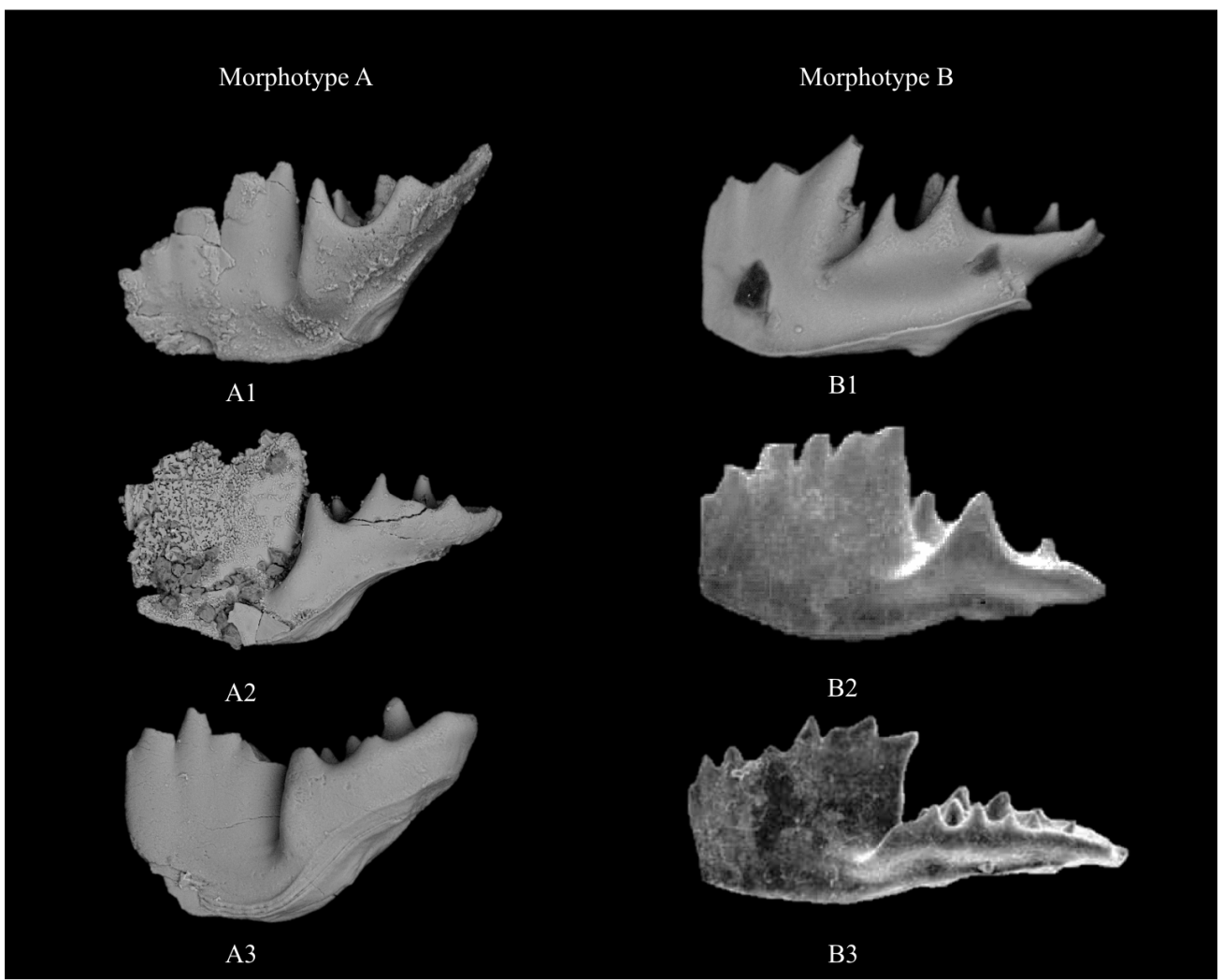

Figure 4. Examples of the two morphotypes (A and B) of Mockina slovakensis. Samples A1 (P2, Poschiedea-Rovadia); A2 (F1, Seazza and Forchiar Creek); A3 (R1, Rio Resartico); B1 (V1, Valmenone); B2 (Onoue and Tanaka, 2005, fig. 3/22a); B3 (Mastandrea et al., 2003, plates 1, 3).

\subsection{Comparison}

Although the M. slovakensis is very common species, it is misidentified frequently. The species owns some distinctive characteristics, especially the abrupt, wall-like posterior end of the blade, which is not present in any other Triassic platform conodont except for its ancestor E. praeslovakensis (Moix et al., 2007). Therefore, the E. praeslovakensis is the species most often thought of as the M. slovakensis in previous literatures. These two species resemble in the abrupt posterior end of the blade and the lateral profile of element. The main reason for the misidentification is the insufficient consideration of the lower side of the conodont element (Moix et al., 2007). The most prominent difference between these two species is the shape of the keel end, E. praeslovakensis owns a distinctive bifurcated keel end but $M$. slovakensis has a pointed or rounded keel terminal which is never bifurcated.

In addition to E. praeslovakensis, M. slovakensis is also easily confused with Mockina postera and Mockina zapfei. Mockina postera also has a short platform like M. slovakensis, but the platform terminal of $M$. postera is always pointed and the posterior platform margins are often asymmetrical. In contrast, the posterior platform end of M. slovakensis is mostly pointed or narrowly rounded, but some specimens have a broad, blunt posterior platform end. Mockina postera has a distinctive anterior denticulation commonly consisting of one prominent denticle on one platform margin and two on the other; $M$. slovakensis usually has three to five denticles on the anterior platform, but there could be also some small nodes occur on the posterior part of the platform, especially in the transitional forms. The blade descends relatively abruptly onto the platform in some M. postera specimen, but in general the last denticle is distinctly smaller than the preceding one; in other specimen, the blade descends gradually into the low carina. Moreover, the blade denticles of $M$. slovakensis are strongly fused, especially in the adults, which never occur on M. postera.

Mockina zapfei has a relatively short platform like other Mockina species, but the platform of M. zapfei is asymmetric due to the curvature of the carina to one side. The most prominent disparities between M. zapfei and M. slovakensis are that M. zapfei owns high blade and it descends gradually into the low carina and the last denticle of carina is projected beyond the platform.

\subsection{Occurrence}

Mockina slovakensis was found by Kozur firstly from beds immediately above the uppermost Norian Misikella hernsteini Zone and below the Rhaetian Misikella posthernsteini Zone. Thus, M. slovakensis was assigned to the uppermost Sevatian, but the age of Rhaetian also cannot be excluded (Moix et al., 2007; Kozur, 1972). Budai and Kovács (1986) assigned $M$. slovakensis to the middle Norian by comparing their fauna with Krystyn's unpublished middle Norian material from Timor Island. Subsequently, Kovács and Nagy (1989) also assigned $M$. slovakensis to the middle Norian mainly based on the unpublished data of Krystyn from Timor and the published data of Budai and Kovács (1986). But they did not exclude early Sevatian age because the occurrence of M. slovakensis together with Rhabdoceras suessi (Moix et al., 2007). Roghi et al. (1995) reported a conodont fauna which was marked by "Epigondolella" 
slovakensis in Dolomia di Forni. They assigned the "Epigondolella" slovakensis to the middle-late Alaunian (middle Norian) based on the unpublished data of Krystyn from Timor and the published data of Budai and Kovács (1986) and Kovács and Nagy (1989). Meço (1999) reported the occurrences of "Epigondolella" slovakensis at the upper part of Sevatian in Albania. Krystyn illustrated the "Epigondolella" slovakensis from Timor in Martini et al. (2000). In the caption of the plates, the "Epigondolella" slovakensis were assigned to the lower Norian, but in the main text they were in the age of middle Norian. The lower Norian could be a literal mistake, because the middle Norian (Alaunian) age was confirmed by the ammonites (Moix et al., 2007; Martini et al., 2000). Nevertheless, the three specimens (in Martini et al., 2000, pl. V, figs. 13-14, 17-18, 21-22) which were assigned to "Epigondolella" slovakensis are actually not the true $M$. slovakensis, cause the wall-like posterior end of the blade which is the most prominent character of M. slovakensis is missed. There is one species (pl. V, figs. 21-22) which has a similar shape of platform and it seems also own a bifurcated keel end from the upper view, but the blade denticles of this specimen is not strongly fused like M. slovakensis. In general, the conodonts presented in Martini et al. (2000) are not real M. slovakensis. Therefore, the approximately Alaunian 1 (middle Norian) age of their "slovakensis" which was confirmed by the ammonites is controversial. Donofrio et al. (2003) reported a conodont fauna which are dominated by M. slovakensis in sediments of the restricted intraplatform basin of the Seefeld Formation, Alps. The middle Norian age of the Seefeld Formation of the Alps is based on two further species, "Epigondolella" carinata and "Epigondolella" postera. However, Kozur held the opinion of that the "Epigondolella" carinata in Donofrio et al. (2003) are actually $M$. slovakensis, due to the two illustrated specimens determined as "E." carinata have a wall like posterior end of the anterior carina. Donofrio et al. (2003) assigned M. slovakensis to Alaunian 2 because that it is concomitant with "E. postera" in "Epigondolella" postera Zone. Channell et al. (2003) found that the $M$. slovakensis occurred in Silická Brezová (Slovakia), and it was assigned to the latest Alaunian. Moix et al. (2007) discussed and revised some of the misidentifications of $M$. slovakensis in previous literature, and then came up with a new species, $E$. praeslovakensis, by using paleontological and biostratigraphic criteria. The E. praeslovakensis was regarded as direct ancestor of M. slovakensis. Moreover, Moix et al. (2007) concluded that monospecific faunas which consist only of true M. slovakensis belong to the Sevatian up to the top of the M. hernsteini Zone, even if its first appearance datum (FAD) is confirmed in latest Alaunian (Channell et al., 2003), where it occurs together with advanced E. praeslovakensis. Monospecific faunas which consist exclusively of E. praeslovakensis belong to the middle to late, but not latest Alaunian. Belvedere et al. (2008) recovered a transitional form of $M$. slovakensis which characterized by a slightly bifurcated keel end along with a real M. slovakensis. They assigned the co-occurrence of E. praeslovakensis and M. slovakensis to latest Alaunian in age according to the discussion in Moix et al. (2007). Balini et al. (2010) found the occurrence of "Epigondolella" slovakensis in Sevatian (upper Norian) in Pizzo Mondello Section. Mazza et al. (2012) also recovered M. slovakensis in the same section and the occurrence of it ranges from
Mockina bidentata Zone to Misikella hernsteini Zone (Sevatian 1 to Sevatian 3). Rigo et al. (2012) documented at Sasso di Castalda Section (Lagonegro Basin, Italy) the first occurrence (FO) of $M$. slovakensis after the M. serrulata and before the FO of $M$. bidentata, and its last occurrence after the FO of Parvigondolella andrusovi and before the FO of M. hernsteini. Mockina slovakensis is also found in the Pignola-Abriola Section in the Lagonegro Basin (Rigo et al., 2016) and Inuyama area, central Japan (Yamashita et al., 2018) in the age of Sevatian. Rigo et al. (2018) took M. slovakensis as the index species of the uppermost Alaunian M. slovakensis Zone in their new Upper Triassic conodont biozonations. The occurrence of M. slovakensis was assigned to the uppermost Alaunian to upper Sevatian.

Combining almost all the information of the distribution of M. slovakensis (Table 1), the occurrence of this species ranges from the base of $M$. slovakensis Zone (uppermost Alaunian) to the uppermost part of $M$. hernsteini Zone (uppermost Sevatian) (Rigo et al., 2018). It's worth to mention that $M$. slovakensis was apparently collected in the same layers of $M$. posthernsteini by Mastandrea et al. (1997). However, the illustrated specimens of $M$. posthernsteini are instead transitional forms with the ancestor (M. hernsteini) because they exhibit more than 3 denticles on the blade and/or they don't show a clear notch on the backside of the cusp, which are the main features of M. posthernsteini (Karádi et al., 2020; Rigo et al., 2018, 2016; Bertinelli et al., 2016; Giordano et al., 2010).

\subsection{Morphocline between Epigondolella praeslovakensis and Mockina slovakensis}

The Epigondolella praeslovakensis is the typical epigondolellid with strongly ornamented platform, considered as the progenitor of Mockina slovakensis (Moix et al., 2007). The adult forms of E. praeslovakensis have a typical lower side of genus Epigondolella with broad and always distinctly bifurcated keel end (Moix et al., 2007). The pit usually lies in behind the central platform. In contrast, the M. slovakensis is usually smaller and simpler than its ancestor. It shows the characteristic features of genus Mockina. The short platform is ornamented at the anterior part of platform margins, but the posterior platform margins is almost smooth. The pit of M. slovakensis usually lies in front of the central platform. The keel end could be pointed or rounded but never bifurcated. The evolutionary trend characterizing the morphocline between $E$. praeslovakensis and $M$. slovakensis consists of a decrease in the number of denticles and a simplification of the platform ornament and the keel end. The platform of E. praeslovakensis tends to simplify by losing ornamentation on the posterior part of the platform margins. The keel end evolves from bifurcated to pointed or rounded. Different transitional forms between E. praeslovakensis and $M$. slovakensis were commonly recorded, of which the most common ones maintain the main characteristics of E. praeslovakensis but without the typical bifurcated keel end, however, it is also different from the advanced M. slovakensis because of its strongly ornamented posterior platform margins.

In summary, the evolution trend from E. praeslovakensis (e.g., bifurcated keel end; ornamented posterior platform margins) to transitional forms (e.g., slightly bifurcated or rounded keel end; ornamented posterior platform margins) and then to 
Table 1 The occurrence of M. slovakensis in different areas

\begin{tabular}{|c|c|c|c|c|c|}
\hline Year & Authors & Occurrence of $M$. slovakensis & Place & MA & MB \\
\hline 1972 & Kozur & Upper Sevatian to lower Rhaetian & Maly Mlynsky Vrch, Slovak Karst, Slovakia & $\times$ & \\
\hline 1986 & Budai and Kovács & Monospecific, exact age unclear & Keszthely Hills, Transdanubian Range, Hungary & $x$ & $x$ \\
\hline 1989 & Kovács and Nagy & Monospecific, exact age unclear & Pilis Hills, Transdanubian Range, Hungary & $x$ & $x$ \\
\hline 1993 & Amodeo et al. & Sevatian & Vietri di Potenza, Lagonegro Basin, Italy & \multicolumn{2}{|c|}{ No figure } \\
\hline 1995 & Roghi et al. & Monospecific, exact age unclear & Dolomia di Forni, Carnia, Southern Alps, Italy & \multicolumn{2}{|c|}{$\times$} \\
\hline 1997 & Mastandrea et al. & Late Norian to Rhaetain & Colle del Crapio, Catena Costiera, Calabria, Italy & \multirow[t]{2}{*}{$\times$} & $x$ \\
\hline 1999 & Meço & Upper Sevatian & Ura Shtrenjte, Cukali zone, Albania & & $x$ \\
\hline 2003 & Donofrio et al. & Supposedly upper Alaunian/lower Sevatian & Seefeld Formation, Tirol, northern Calcarous Alps, Austria & $x$ & $x$ \\
\hline 2003 & Channell et al. & Sevatian & Silická Brezová, Slovak Karst, Slovakia & $\times$ & $\times$ \\
\hline 2003 & Mastandrea et al. & Monospecific, exact age unclear & Valle Corvino, Calabria, Italy & & $\times$ \\
\hline 2005 & Onoue and Tanaka & Presumably upper Alaunian & Sambosan accretionary complex, Japan & $x$ & $\times$ \\
\hline 2007 & Moix et al. & Uppermost Alaunian to upper Sevatian & Gavuruçtuğu Block, Mersin Mélange, Turkey & \multicolumn{2}{|c|}{ No figure } \\
\hline 2008 & Belvedere et al. & Uppermost Alaunian & Monte Pasubio, Southern Alps, Italy & \multicolumn{2}{|c|}{$\times$} \\
\hline 2010 & Balini et al. & Sevatian & Pizzo Mondello, Sicani Basin, Sicily, Italy & \multicolumn{2}{|c|}{ No figure } \\
\hline 2012 & Mazza et al. & Sevatian 1 to Sevatian 3 & Pizzo Mondello, Sicani Basin, Sicily, Italy & $\times$ & $\times$ \\
\hline 2012 & Rigo et al. & Alaunian 3 to Sevatian 2 & Sasso di Castalda, Lagonegro Basin, Italy & \multicolumn{2}{|c|}{ No figure } \\
\hline 2016 & Rigo et al. & Sevatian & Pignola-Abriola, Lagonegro Basin, Italy & \multicolumn{2}{|c|}{$\times$} \\
\hline 2018 & Yamashita et al. & Sevatian & Inuyama area, Japan & \multicolumn{2}{|l|}{$x$} \\
\hline
\end{tabular}

MA. Morphotype A; MB. morphotype B. Cross mark only represents the occurrence, but not the exact range of the morphotypes in the relevant section.

M. slovakensis (e.g., pointed or rounded keel end; usually neat posterior platform margins) is a process of simplification and miniaturization. Coincidentally, the process of simplification and miniaturization from E. praeslovakensis to M. slovakensis is consistent with the trend of the whole conodont evolution during the Norian (Karádi et al., 2020; Rigo et al., 2018).

\subsection{Potential Lifestyle of Mockina slovakensis}

Mockina slovakensis was thought to solely live in restricted environments as it was usually found in the Upper Triassic intraplatform basins, such as the Rezi Dolomite Formation and Feketehegy Formation in Hungary (Kovács and Nagy, 1989; Budai and Kovács, 1986), Dolomia di Forni Formation in Italy (Roghi et al., 1995) and Seefeld Formation in Austria (Donofrio et al., 2003). Nevertheless, Meço (1999) reported the occurrences of "Epigondolella" slovakensis in a pelagic environment in Albania. Channell et al. (2003) stated that this species is rare in open sea environments, while it is very common in Norian intraplatform basins, which can be only dated by M. slovakensis. More and more reports indicate that the open marine environments are also suitable for subsistence of M. slovakensis (Rigo et al., 2016, 2012; Mazza et al., 2012; Balini et al., 2010), and also in bedded cherts deposited below the CCD (Yamashita et al., 2018). It was even found in shallow water limestone belong to carbonate platform condition (Belvedere et al., 2008). Mockina slovakensis was also analyzed for oxygen isotopic composition, the analyses of which suggest that this species throve in the warmer and upper part of the column water (Trotter et al., 2015).

In summary, M. slovakensis is surface dweller species living in different marine environments, from (hemi)pelagic deep ocean to shallow water carbonate platform, including intraplatform basins (Fig. 5).

\subsection{Paleogeographic Implications}

The evolution of the Norian shallow-water carbonate platforms and adjacent basins is controlled by the rifting phases connected to the westward propagation of the Neotethys Ocean opening and to the early phases of the Ligurian-Piedmont Ocean opening in the west. Extensional tectonic phases in the Norian re-activated the NNE-SSW, NE-SW and E-W oriented faults, controlling the establishment and position of the Dolomia Principale shallow-water carbonate platform together with the development of the intraplatform basins represented by the Dolomia di Forni Formation (Cozzi, 2000). The presence of different outcrops of the Dolomia di Forni in the Carnian and Julian Prealps might be explained as portions of a single deeper basin, named Carnian Basin, fragmented during the Alpine orogeny (Scotti et al., 2002) or as isolated intraplatform basins developed due to the Triassic synsedimentary tectonic.

In the studied sections of the Dolomia di Forni Formation (i.e., Valmenone, Poschiedea-Rovaia area, Verzegnis, Seazza and Forchiar Creek, Rio Resartico area), M. slovakensis was documented as almost monospecific conodont association. This species was also documented in other coeval intraplatform basins, such as in the Seefeld Schichten, in the northern Calcareous Alps (southern Austria) (Donofrio et al., 2003), in the Rezi Dolomite Formation and the Feketehegy Formation in Hungary (Kovács and Nagy, 1989; Budai and Kovács, 1986) and in the lower part of the "metacarbonate unit" cropping out in the NW Anatolia (Kaya et al., 2001). Even if M. slovakensis represented the majority of the collected species from the intraplatform basins where it was documented, this species has occurred in the Dolomia di Forni and Seefeld Schichten along with other rare species, that are M. postera, M. carinata and E. praeslovakensis (Donofrio et al., 2003). Mockina slovakensis was also documented in open pelagic/hemipelagic basins, such as Lagonegro Basins (Rigo et al., 2012), Albania (Meço, 1999), Slovakia (Channell et al., 2003), Mount Cocuzzo basinal succession in southern Italy (Mastandrea et al., 1997), in Sicily at Pizzo Mondello (Mazza et al., 2012) and in the Inuyama area, Japan 


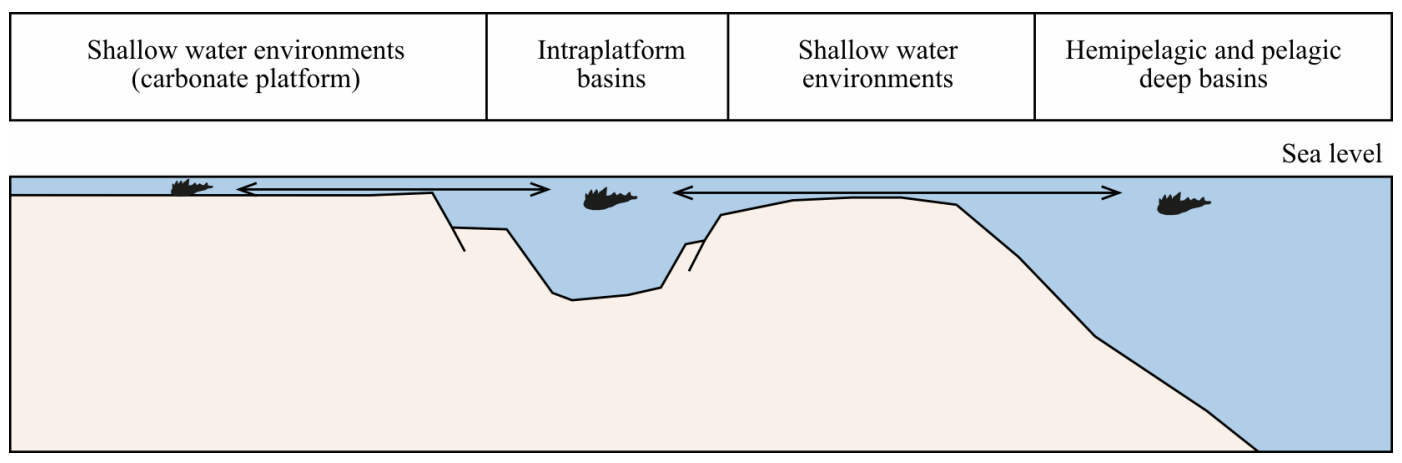

Figure 5. Schematic lifestyle interpretation of Mockina slovakensis.

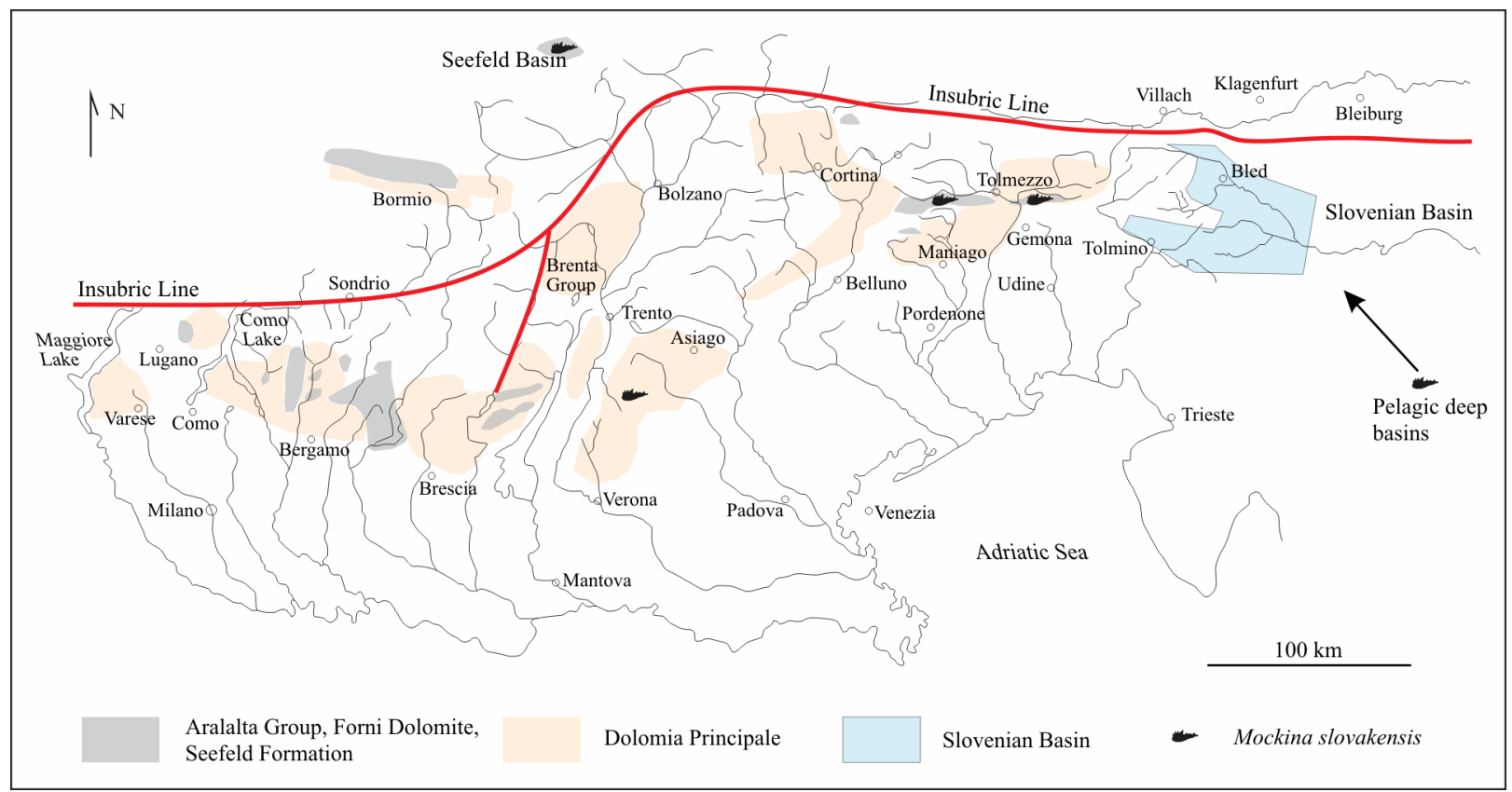

Figure 6. Outcrops of the Dolomia Principale Formation (in pink) and the intraplatform basins (in gray) in the Alps. Pelagic, open marine sediments are shown in light blue (Slovenian Basin). The stylized black conodonts testified the findings of the conodont M. slovakensis.

(Yamashita et al., 2018). Moreover, it was also documented in the very shallow water environment like the carbonate platform represented by the Dolomia Principale Formation (Belvedere et al., 2008).

The versatility of $M$. slovakensis can thus explain its spreading through different depositional environments and its prolificacy in intraplatform basins where other species probably suffered from the restricted conditions. However, the finding of other species, such as M. postera, M. carinata and its ancestor E. praeslovakensis, allows suggesting direct connections among the Tethys Ocean and the intraplatform basins of the Forni Dolomite and Seedfeld Schichten, at least for a limited period of geologic time. It is noteworthy that further to the west, the Lombardy intraplatform basins (e.g., Aralalta Group) have not provided any conodonts yet, and it needs to be investigated together with the Ortles and Quattervals Nappes in the central Austroalpine to understand if the Tethyan connection extended also to the western sectors. The spreading of this species might be fundamental to unravel the presence of a possible passageway from the Tethys Ocean to the western sector of the southern and northern Alps, at least during the Late Triassic (Fig. 6).

\section{CONCLUSIONS}

New conodont assemblage in the successions of Dolomia di Forni Formation is dominated by Mockina slovakensis, along with a small number of Mockina postera and Epigondolella praeslovakensis. The integration of data from the new studies and available literature points out that the M. slovakensis population shows various morphological characteristics. We thus suggested two new morphotypes of M. slovakensis, morphotypes A and B, on the basis of shape of the lateral profile. These two morphotypes have been documented also in its ancestor $E$. praeslovakensis. We emended the description of M. slovakensis; we discussed its occurrence and its stratigraphic range that is uppermost Alaunian 3 to upper Sevatian 2.

The versatile lifestyle of $M$. slovakensis permitted this species to adapt to different environments from shallow to deep open marine environments. It is also a typical conodont element usually documented as almost monospecific conodont association in coeval intraplatform basins and it proved being a useful fossil to understand the geodynamic evolution of the Late Triassic sector of the western Tethys. 


\section{ACKNOWLEDGMENTS}

This research was supported by the Italian MIUR (Ministero dell'Istruzione, dell'Università e della Ricerca) to Manuel Rigo (No. 2017W2MARE) and China Scholarship Council to Yixing Du (No. 201708510096). Thanks to the two anonymous reviewers for their constructive comments. Open Access funding provided by Università degli Studi di Padova. The final publication is available at Springer via https://doi.org/ 10.1007/s12583-021-1411-5.

Open Access This article is distributed under the terms of the Creative Commons Attribution 4.0 International License (http://creativecommons.org/licenses/by/4.0/), which permits unrestricted use, distribution, and reproduction in any medium, provided you give appropriate credit to the original author and the source, provide a link to the Creative Commons license, and indicate if changes were made.

\section{REFERENCES CITED}

Amodeo, F., Molisso, F., Kozur, H., et al., 1993. Age of Transitional Beds from «Cherty Limestones» (Calcari con Selce) to «Radiolarites» (Scisti Silicei) in the Lagonegro Domain (Southern Italy). First Evicence of Rhaetain Conodonts in Peninsular Italy. Bollettino del Servizio Geologico d'Italia, CX(3-22): 3-21

Balini, M., Bertinelli, A., Di Stefano, P., et al., 2010. The Late CarnianRhaetian Succession at Pizzo Mondello (Sicani Mountains). Albertiana, 39: $36-57$

Bazzucchi, P., Bertinelli, A., Ciarapica, G., et al., 2005. The Late TriassicJurassic Stratigraphic Succession of Pignola (Lagonegro-Molise Basin, Southern Apennines, Italy). Bollettino della Società Geologica Italiana, 124(1): 143-153

Belvedere, M., Avanzini, M., Mietto, P., et al., 2008. Norian Dinosaur Footprints from the "Strada delle Gallerie" (Monte Pasubio, NE Italy). Studi Trentini Di Scienza Naturali, Acta Geologica, 83: 267-276

Berra, F., 1995. Stratigraphic Evolution of a Norian Intraplatform Basin Recorded in the Quattervals Nappe (Austroalpine, Northern Italy) and Paleogeographic Implications. Eclogae Geologicae Helvetiae, 88(3): 501-528

Berra, F., Jadoul, F., 1999. Stratigraphy, Paleogeography and Tectonic Setting of the Norian Succession of the Ortles Nappe (Central Austroalpine, Lombardy, Northern Italy). In: Gosso, G., Jadoul, F., Sella, M., et al., eds., 3rd Workshop on Alpine Geologicak Studies. Sept. 29-Oct. 1, 1997, Biella-Oropa. 78-89

Berra, F., Delfrati, L., Ponton, M., 2007. Dolomia Principale. Carta Geologica d'Italia 1 : 50 000. Catalogo Delle Formazioni-unità Tradizionali, (2): 63-72

Berra, F., Jadoul, F., Anelli, A., 2010. Environmental Control on the End of the Dolomia Principale/Hauptdolomit Depositional System in the Central Alps: Coupling Sea-Level and Climate Changes. Palaeogeography, Palaeoclimatology, Palaeoecology, 290(1-4): 138-150. https://doi.org/10.1016/j.palaeo.2009.06.037

Bertinelli, A., Casacci, M., Concheri, G., et al., 2016. The Norian/Rhaetian Boundary Interval at Pignola-Abriola Section (Southern Apennines, Italy) as a GSSP Candidate for the Rhaetian Stage: An Update. Albertiana, 43: 5-18

Brandner, R., Poleschinski, W., 1986. Stratigraphie und Tektonik am Kalkalpensüdrand zwischen Zirl und Seefeld in Tirol (Exkursion D am 3. April 1986). Jahresberichte und Mitteilungen des Oberrheinischen Geologischen Vereins, 67-92
Budai, T., Kovács, S., 1986. Contributions to the Stratigraphy of the Rezi Dolomite Formation Metapolygnathus slovakensis (Conodonta, Upper Triassic) from the Keszthely Mts (W Hungary). Annual Report of the Geological Institute of Hungary, 1984: 175-191

Budurov, K. J., Sudar, M. N., 1990. Late Triassic Conodont Stratigraphy. Courier Forschungsinstitut Senckenberg, 118: 203-239

Buser, S., 1989. Development of the Dinaric and the Julian Carbonate Platforms and of the Intermediate Slovenian Basin (NW Yugoslavia). Bollettino della Società Geologica Italiana, 40: 313-320

Buser, S., 1996. Geology of Western Slovenia and Its Paleogeographic Evolution. In: Drobne, K., Goričan, Š., Kotnik, B., eds., The Role of Impact Processes and Biological Evolution of Planet Earth-International Workshop. ZRC Publ., ZRC SAZU, Ljubljana. 111-123

Carulli, G. B., Longo Salvador, G., Ponton, M., et al., 1997. La Dolomia di Forni: Evoluzione di un Bacino Euxinico Tardo-Triassico nelle Prealpi Carniche. Bollettino della Società Geologica Italiana, 116(1): 95-107

Carulli, G. B., Cozzi, A., Longo Salvador, G., et al., 2000. Geologia delle Prealpi Carniche (con Carta Geologica delle Prealpi Carniche alla Scala 1 : 50000 e Note Illustrative alla Carta Geologica delle Prealpi Carniche). Pubbl. Mus. Friul. St. Nat., Udine. 44

Channell, J. E. T., Kozur, H. W., Sievers, T., et al., 2003. Carnian-Norian Biomagnetostratigraphy at Silická Brezová (Slovakia): Correlation to Other Tethyan Sections and to the Newark Basin. Palaeogeography, Palaeoclimatology, Palaeoecology, 191(2): 65-109. https://doi.org/10.1016/s0031-0182(02)006545

Cousin, M., 1973. Le Sillon Slovene: Les Formations Triasiques, Jurassiques et Ndocomiennes au Nord-Est de Tohnin (Slovdnie Occidentale, Alpes Mdridionales) et leurs Affinite Dinarique. Bulletin de la Société Géologique de France, 15: 326-339

Cousin, M., 1981. Les Rapports Alpes-Dinarides: Les Confins de 1'Italie et de Yougoslavie. Vol. I. Société Géologique du Nord, 5: 1-521

Cozzi, A., 2000. The Effects of Extensional Tectonics on Shallow Water Carbonate Platform Facies and Geometry: The Case of the Upper Triassic Dolomia Principale, Carnian Prealps, Northern Italy. AAPG Annual Convention, New Orleans, Louisiana. \#90914

Cozzi, A., 2002. Facies Patterns of a Tectonically-Controlled Upper Triassic Platform-Slope Carbonate Depositional System (Carnian Prealps, Northeastern Italy). Facies, 47(1): 151-178. https://doi.org/10.1007/bf02667711

Cozzi, A., Hardie, L. A., 2003. Third-Order Depositional Sequences Controlled by Synsedimentary Extensional Tectonics: Evidence from Upper Triassic Carbonates of the Carnian Prealps (NE Italy). Terra Nova, 15(1): 40-45. https://doi.org/10.1046/j.1365-3121.2003.00461.x

Cozzi, A., Jäger, H., 2000. Sedimentology, Palynofacies and Significance of an Intraplatform Anoxic Depression within the Upper Triassic Dolomia Principale (Carnian Prealps, Northern Italy). In: Abstr. 80th Summer Meeting Società Geologica Italiana. Sept. 6-8, 2000, Trieste. 164-165

Csillag, G., Budai, T., Gyalog, L., 1995. Contribution to the Upper Triassic Geology of the Keszthely Mountains (Transdanubian Range), Western Hungary. Acta Geologica Hungarica, 38(2): 111-129

Dal Corso, J., Ruffell, A., Preto, N., 2019. Carnian (Late Triassic) C-Isotope Excursions, Environmental Changes, and Biotic Turnover: A Global Perturbation of the Earth's Surface System. Journal of the Geological Society, 176(1): 129-131. https://doi.org/10.1144/jgs2018-217

Dalla Vecchia, F. M., Muscio, G., 1991. I Fossili della Dolomia di Forni (Norico-Prealpi Carniche, Udine). Paleocronache, (1): 9-19

Donofrio, D. A., Brandner, R., Poleschinski, W., 2003. Conodonten der Seefeld-Formation: Ein Beitrag zur Bio- und Lithostratigraphie der Hauptdolomit-Plattform (Obertrias, Westliche Nördliche Kalkalpen, 
Tirol). Geologisch-Paläontologische Mitteilungen Innsbruck, 26: 91-107

Fantoni, R., Salvador, G. L., Podda, F., et al., 1998. L'unità a Laminiti Organiche nel Norico del Rio Resartico (Val Resia, Prealpi Giulie). Atti Ticinensi di Scienze Della Terra, 7(Suppl.): 109-123

Fruth, I., Scherreiks, R., 1984. Hauptdolomit—Sedimentary and Paleogeographic Models (Norian, Northern Calcareous Alps). Geologische Rundschau, 73(1): 305-319. https://doi.org/10.1007/bf01820372

Giordano, N., Rigo, M., Ciarapica, G., et al., 2010. New Biostratigraphical Constraints for the Norian/Rhaetian Boundary: Data from Lagonegro Basin, Southern Apennines, Italy. Lethaia, 43: 573-586. https://doi.org/10.1111/j.1502-3931.2010.00219.x

Gullo, M., 1996. Conodont Biostratigraphy of Uppermost Triassic Deep-Water Calcilutites from Pizzo Mondello (Sicani Mountains): Evidence for Rhaetian Pelagites in Sicily. Palaeogeography, Palaeoclimate, Palaeoecology, 126: 309-323. https://doi.org/10.1016/s0031-0182(96)00043-0

Haas, J., Kovács, S., Krystyn, L., et al., 1995. Significance of Late Permian-Triassic Facies Zones in Terrane Reconstructions in the Alpine-North Pannonian Domain. Tectonophysics, 242(1/2): 19-40. https://doi.org/10.1016/0040-1951(94)00157-5

Haas, J., 2002. Origin and Evolution of Late Triassic Backplatform and Intraplatform Basins in the Transdanubian Range, Hungary. Geologica Carpathica, 53(3): 159-178

Jadoul, F., 1985. Stratigrafia e Paleogeografia del Norico nelle Prealpi Bergamasche Occidentali. Rivista Italiana di Paleontologia $e$ Stratigrafia, 91: 479-512

Karádi, V., Cau, A., Mazza, M., et al., 2020. The Last Phase of Conodont Evolution during the Late Triassic: Integrating Biostratigraphic and Phylogenetic Approaches. Palaeogeography, Palaeoclimatology, Palaeoecology, 549: 109144. https://doi.org/10.1016/j.palaeo.2019.03.045

Kaya, O., Helvaci, H., Kozur, H., et al., 2001. Late Norian Conodont Age for a Metacarbonate Unit in NW Anatolia, Turkey. Geobios, 34(5): 527-532. https://doi.org/10.1016/s0016-6995(01)80067-x

Kovács, S., Nagy, G., 1989. Contribution to the Age of the Avicula- and Halobia-Limestones (Feketehegy Limestone Formation) in Pilis Mts (NE Transdanubian Central Range, Hungary). Annual Report of the Hungarian Geological Institute, 1987: 95-129

Kozur, H. W., 1972. Die Conodontengattung Metapolygnathus Hayashi 1968 und ihr Stratigraphischer wert. Geologisch-Paläontologische Mitteilungen Innsbruck, 2(11): 1-37

Martini, R., Zaninetti, L., Villeneuve, M., et al., 2000. Triassic Pelagic Deposits of Timor: Palaeogeographic and Sea-Level Implications. Palaeogeography, Palaeoclimatolology, Palaeoecology, 160(1/2): 123-151. https://doi.org/10.1016/s0031-0182(00)00062-6

Mastandrea, A., Ietto, F., Neri, C., et al., 1997. Conodont Biostratigraphy of the Late Triassic Sequence of Monte Cocuzzo (Catena Costiera, Calabria, Italy). Rivista Italiana di Paleontologia e Stratigrafia, 103(2): 173-182

Mastandrea, A., Perri, E., Neri, C., et al., 2003. Conodont Biostratigraphy of the Norian-Rhaetian Deposits in the Northern Calabria: The Valle Corvino and Grisolia Sections. Bollettino-Societa Paleontologica Italiana, 42(1/2): 39-48

Mattavelli, L., Rizzini, A., 1974. Facies Euxiniche nelle Dolomie Noriche dell'Ampezzano (Udine): Petrografia e Sedimentologia. In: Contributi Strat. Paleog. Mesozoico Tetide. Memorie della Rivista Italiana di Paleontologia e Stratigrafia, 14: 111-140

Mazza, M., Rigo, M., Gullo, M., 2012. Taxonomy and Biostratigraphic Record of the Upper Triassic Conodonts of the Pizzo Mondello Section
(Western Sicily, Italy), GSSP Candidate for the Base of the Norian. Rivista Italiana di Paleontologia e Stratigrafia, 118(1): 85-130

Meço, S., 1999. Conodont Biostratigraphy of Triassic Pelagic Strata, Albania. Rivista Italiana di Paleontologia e Stratigrafia, 105(2): 251-266

Moix, P., Kozur, H. W., Stampfli, G. M., et al., 2007. New Paleontological, Biostratigraphical and Paleogeographic Results from the Triassic of the Mersin Mélange, SE Turkey. The Global Triassic. New Mexico Museum of Natural History and Science Bulletin, 41: 282-311

Onoue, T., Tanaka, H., 2005. Late Triassic Bivalves from Sambosan Accretionary Complex, Southwest Japan, and Their Biogeographic Implications. Paleontological Research, 9(1): 15-25. https://doi.org/10.2517/prpsj.9.15

Ponton, M., 2017. Dolomie Bituminose nella Dolomia Principale: La Miniera del Rio Resartico (Prealpi Giulie-Italia). Gortania: Geologia Paleontologia Paletnologia, 38: 9-37 (in Italian)

Rigo, M., Bertinelli, A., Concheri, G., et al., 2016. The Pignola-Abriola Section (Southern Apennines, Italy): A New GSSP Candidate for the Base of the Rhaetian Stage. Lethaia, 49: 287-306. https://doi.org/10.1111/let.12145

Rigo, M., Mazza, M., Karádi, V., et al., 2018. New Upper Triassic Conodont Biozonation on of the Tethyan Realm. In: Tanner, L. H., ed., The Late Triassic World: Earth in a Time of Transition. Topics in Geobiology, 46: 189-235. https://doi.org/10.1007/978-3-319-68009-5_6

Rigo, M., Preto, N., Roghi, G., et al., 2007. A Rise in the Carbonate Compensation Depth of Western Tethys in the Carnian (Late Triassic): Deep-Water Evidence for the Carnian Pluvial Event. Palaeogeography, Palaeoclimatology, Palaeoecology, 246(2-4): 188-205. https://doi.org/10.1016/j.palaeo.2006.09.013

Rigo, M., Preto, N., Franceschi, M., et al., 2012. Stratigraphy of the Carnian-Norian Calcari con Selce Formation in the Lagonegro Basin, Southern Apennines. Rivista Italiana di Paleontologia e Stratigrafia, 118(1): 143-154

Roghi, G., Mietto, P., Vecchia, D., 1995. Contribution to the Conodont Biostratigraphy of the Dolomia di Forni (Upper Triassic, Carnia, NE Italy). Memoire di Scienze Geologiche, 47: 125-133

Rožič, B., Kolar-Jurkovšek, T., Šmuc, A., 2009. Late Triassic Sedimentary Evolution of Slovenian Basin (Eastern Southern Alps): Description and Correlation of the Slatnik Formation. Facies, 55(1): 137-155. https://doi.org/10.1007/s10347-008-0164-2

Schmid, S. M., Fügenschuh, B., Kissling, E., et al., 2004. Tectonic Map and Overall Architecture of the Alpine Orogen. Eclogae Geologicae Helvetiae, 97(1): 93-117. https://doi.org/10.1007/s00015-004-1113-x

Scotti, P., Fantoni, R., Podda, F., et al., 2002. Depositi Norici di Ambiente Anossico nelle Prealpi Friulane (Italia Nord-Orientale). Mem. Soc. Geol. It., 57: 65-78

Simms, M. J., Ruffell, A. H., 1989. Synchroneity of Climatic Change and Extinctions in the Late Triassic. Geology, 17(3): 265-268. https://doi.org/10.1130/0091-7613(1989)017<0265:soccae $>2.3 . c o ; 2$

Trotter, J. A., Williams, I. S., Nicora, A., et al., 2015. Long-Term Cycles of Triassic Climate Change: A New $\delta^{18} \mathrm{O}$ Record from Conodont Apatite. Earth and Planetary Science Letters, 415: 165-174. https://doi.org/10.1016/j.eps1.2015.01.038

Yamashita, D., Kato, H., Onoue, T., et al., 2018. Integrated Upper Triassic Conodont and Radiolarian Biostratigraphies of the Panthalassa Ocean. Paleontological Research, 22(2): 167-197. https://doi.org/10.2517/2017pr020 